\title{
PEMBERANTASAN PENYALAHGUNAAN DAN PEREDARAN NARKOTIKA MELALUI PARAREM DESA ADAT PANCASARI
}

\author{
Kadek Andy Krisnanta, I Made Suwitra, I Wayan Arthanaya \\ Fakultas Hukum Universitas Warmadewa, Denpasar - Bali, Indonesia
}

\begin{abstract}
Abstrak
Peningkatan penyebaran Narkotika di Indonesia dipengaruhi oleh pertumbuhan penduduk yang sangat pesat. Bali merupakan salah satu daerah tujuan wisata yang telah mendunia dan mulai menjadi sasaran penyebaran narkotika dan bahan berbahaya lainnya. Pemberantasan narkotika di Bali sangat memerlukan sinergitas dari berbagai komponen dalam rangka menekan dan membatasi ruang gerak pengedar baik dalam skala kecil maupun besar. Upaya kerjasama pemberantasan peredaran dan penyalahgunaan narkotika dilakukan oleh BNNK Buleleng dengan menggandeng desa adat melalui penciptaan pararem tentang Narkotika di Desa Pancasari, Kabupaten Buleleng. Penelitian ini menggunakan metode hukum empiris. Data dianalisis secara kualitatif, deskriptif serta sistematis. Kerjasama BNNK Buleleng dengan Desa Adat Pancasari dalam bentuk Pararem Nomor 01/DPP-II/2019 tentang Narkotika yang digunakan sebagai alat untuk memberantas keberadaan narkotika dengan tujuan untuk membatasi ruang gerak peredarannya mulai dari lingkup masyarakat terkecil. Kemudian, efektivitas Pararem Nomor 01/DPP-11/2019 dalam rangka pemberantasan penyalahgunaan dan peredaran Narkotika di Desa Adat Pancasari sudah berjalan efektif dengan dukungan penuh pemerintah desa dan masyarakat adat serta peran serta BNNK Buleleng sebagai pengawas sehingga sampai saat ini tidak ada pelanggaran terhadap pararem tersebut di Desa Adat Pancasari.
\end{abstract}

Kata Kunci: BNN; Desa Adat; Penyalahgunaan Narkotika

\begin{abstract}
The increase in the spread of narcotics in Indonesia is influenced by the rapid population growth. Bali is one of the global tourist destinations and has become a spot for the spread of narcotics and other dangerous substances. The eradication of narcotics in the area in turn requires the synergy of various components in order to suppress and limit the space for dealers both small and large scale. The collaborative effort to eradicate the distribution and abuse of narcotics is carried out by BNNK Buleleng by cooperating with traditional villages through the issuance of a pararem concerning Narcotics in Desa Pancasari, the Sub-district of Buleleng. This research makes use of empirical legal methods. Data were analysed qualitatively, descriptively and systematically. The collaboration between BNNK Buleleng and the Desa Adat of Pancasari in the form of Pararem Number 01/DPP-II/2019 concerning Narcotics is used as a tool to eradicate the existence of narcotics with the aim to limit the space for spread starting from the smallest scope of society. Then, in terms of effectiveness, the Pararem Number 01/DPP-11/2019 in the eradication of narcotics abuse and circulation in the Desa Adat of Pancasari has been effective with the full support of the village government and indigenous peoples as well as the role of the BNNK Buleleng as a supervisor that until now there has been no violation of the Pararem in the indigenous villages of Pancasari.
\end{abstract}

Keywords: National Narcotics Agency; Customary Village; Abuse of Narcotics

\section{PENDAHULUAN}

Penyalahgunaan narkotika saat ini menjadi suatu masalah yang semakin kompleks. Penyalahgunaan narkotika dapat merusak tatanan kehidupan keluarga, lingkungan masyarakat bahkan negara (Sanger, 2013:3). Meningkatnya penyebaran narkoba di Indonesia karena pertumbuhan penduduk yang semakin pesat sehingga hal ini dimanfaatkan oleh mafia Narkotika untuk memasarkan barang haram di wilayah Indonesia.

Bali sebagai daerah tujuan wisata yang telah mendunia sangat rentan terhadap penyebaraan narkotika dan bahan berbahaya jenis lainnya. Untuk itu dibutuhkan sinergi dari berbagai stakeholder dalam menekan dan memberantas ruang gerak pengedar narkoba, baik yang bersekala besar maupun bersekala kecil. Walaupun menurut Kepala Badan Narkotika Nasional (selanjutnya disebut BNN) 
Republik Indonesia Komjen Polisi Heru Winarko bahwa Bali sesungguhnya memiliki ketahanan paling baik terhadap peredaran narkoba, namun antisipasi terus dibutuhkan melalui kerja sama dengan masyarakat melalui desa adat.

Upaya kerja sama tersebut dilakukan dengan menggandeng desa adat dalam memerangi penyebaran narkoba melalui penciptaan perarem atau awig-awig yang dapat memberikan sanksi sosial bagi masyarakat. Penciptaan perarem atau awig-awig di dasarkan pada hukum positif yang berlaku seperti Undang- Undang Dasar Tahun 1945 pasal 18 b ayat 2 yang menyatakan bahwa "Negara mengakui dan menghormati kesatuan-kesatuan masyarakat hukum adat beserta hak hak tradisionalnya sepanjang masih hidup dan sesuai dengan perkembangan masyarakat dan prinsip negara kesatuan republik indonesia,yang di atur dalam undang-undang".

Penegakan hukum dalam rangka memberantas tindak pidana penyalahgunaan narkotika, peran BNN dan desa adat melakukan kerjasama dalam memberantas penyalahgunaan dan peredaran gelap narkotika untuk mewujudkan tujuan pembangunan nasional dan perlu dilakukan upaya berkelanjutan disegala bidang antara lain pembangunan kesejahtraan rakyat, kesehatan dalam hal pencegahan penyalahgunaan dan peredaran gelap narkotika dan/atau sejenisnya. Pemberantasan peredaran gelap narkotika dan presekusor narkotika yang dilakukan atas dasar kerjasama BNN dengan Desa Pakraman Pancasari adalah bentuk kecil dari pemberantasan peredaran gelap narkotika yang bertujuan untuk hal besar yaitu menghilangkan ancaman narkotika di Desa tersebut.

Berdasarkan dari uraian latar belakang diatas, adapun rumusan masalah yang akan penulis bahas yaitu:

1. Bagaimana bentuk kerjasama yang dilakukan BNN dan desa adat dalam melakukan pencegahan dan pemberantasan penyalahgunaan serta peredaran gelap narkotika?

2. Bagaimana efektivitas Pararem No.: 1/DPP-II/2019 tentang Narkotika dalam mencegah dan memberantas penyalahgunaan serta peredaran gelap narkotika di Desa Pancasari, Kecamatan Sukasada, Kabupaten Buleleng?

Adapun tujuan penulisan dari penelitian ini yaitu:

1. Mengetaui dan memahami bentuk kerjasama yang dilakukan BNN dan desa adat dalam melakukan pencegahan dan pemberantasan penyalahgunaan serta peredaran gelap narkotika.

2. Menganalisis efektivitas Pararem No. 1/DPP-II/2019 tentang Narkotika dalam mencegah dan memberantas penyalahgunaan serta peredaran gelap narkotika di Desa Pancasari, Kecamatan Sukasada, Kabupaten Buleleng.

\section{METODE PENELITIAN}

Dalam penelitian ini penulis menggunakan metode penelitian hukum empiris yaitu penelitian yang mengacu pada kenyataan hukum yang mencakup kenyataan-kenyataan sosial atau budayanya. Penelitian terhadap efektivitas hukum tertulis maupun kebiasaan yang tercatat pada dasarnya merupakan kesenjangan antara norma dan realitas hukum. Pendekatan yang digunakan adalah pendekatan yuridis sosiologis yang digunakan untuk mengidentifikasi dan mengkonsepsi hukum sebagai institusi sosial yang riil dan fungsional dalam sistem kehidupan yang nyata (Soerjono, 1986: 51). Kemudian pendekatan perundang-undangan bertujuan untuk menelaah semua regulasi peraturan perundang-undangan yang bersangkut paut dengan masalah yang diteliti yaitu Narkotika.

Adapun sumber data hukum yang digunakan penulis yakni penelitian dan kepustakaan berupa:

1. Data hukum primer yang digunakan adalah hasil wawancara secara langsung dari lapangan kepada Kepala Desa Pakraman Pancasari, Prajuru Adat Desa Pakraman Pancasari, Masyarakat Adat Desa Pakraman Pancasari, BNNK Buleleng dengan lokasi penelitian di Desa Pancasari, Kecamatan Sukasada Kabupaten Buleleng.

2. Data hukum sekunder diperoleh dari buku-buku tentang hukum adat, efektivitas hukum dan pemberantasan narkotika di Indonesia.

Teknik pengumpulan data berupa bahan hukum yang dipergunakan adalah studi dokumen dengan cara menelaah bahan-bahan pustaka yang relevan dengan penelitian berupa literatur, karya ilmiah, peraturan perundang-undangan yang terkait dengan hukum adat dan pemberantasan narkotika (Hariyono, 2009) . Kemudian wawancara dilakukan dengan pihak-pihak yang terkait dengan objek yang menjadi masalah dalam pembahasan. Teknik wawancara kepada BNNK Buleleng, Kepala 
Desa dan Prajuru Adat Desa Adat Pancasari. Kemudian informan adalah warga desa Pakrama Pancasari.

Setelah mendapatkan data yang diinginkan, data penelitian diolah dan dianalisis secara kualitatif yaitu data disajikan bukan dalam bentuk angka melainkan data-data yang wujudnya dalam bentuk kata-kata yang nantinya akan disusun secara sistematis. Kemudian dilakukan interpretasi untuk memahami makna data dalam situasi yang terjadi dengan aturan yang ada. Kemudian dilakukan penafsiran dari perspektif peneliti setelah memahami keseluruhan kualitas data agar menghasilkan suatu kesimpulan dari sebuah penelitian.

\section{HASIL PENELITIAN DAN PEMBAHASAN \\ Kerjasama BNN dan Desa Adat dalam Mencegah dan Memberantas Penyalahgunaan dan Peredaran Gelap Narkotika}

Narkotika merupakan salah satu jenis zat yang merupakan obat dan apabila disalahgunakan dapat membawa efek atau pengaruh tertentu pada tubuh dan psikis seseorang misalnya kesadaran dan prilaku. Pengaruh yang ditimbulkan berupa rasa tenang, rangsangan dan halusinasi (Siswanto, 2008: 1). Selain Jepang, Thailand, Malaysia, Fhilipina dan Hongkong, Indonesia juga masuk dalam daftar tertinggi negara yang menjadi sasaran mafia Narkotika. Narkotika yang berjenis ektasi awalnya hanya populer di Eropa terutama Belanda, namun sekarang telah masuk keseluruh dunia tidak terkecuali Indonesia (Makaro \& Dkk, 2005: 2).

Letak Indonesia yang sangat strategis serta memiliki banyak pulau besar dan garis pantai yang panjang sehingga menjadi incaran para mafia narkotika untuk mengedarkan narkotika. Jumlah penduduk Indonesia yang semakin tahun terus bertambah terutama generasi muda yang merupakan penerus bangsa dan sangat rentan terpengaruh penyalahgunaan Narkotika. Banyaknya kesempatan dan pengawasan yang kurang terutama pada bandara dan pelabuhan menyebabkan masuknya peredaran narkotika dengan sangat mudah (Makaro \& Dkk, 2005: 3).

Perkembangan teknologi juga mempengaruhi peningkatan peredaran dan penyalahgunaan narkotika baik dari jumlah maupun jenis transaksi terutama dalam perdagangan gelap narkotika dengan memanfaatkan internet. Penyalahgunaan narkotika meningkat dengan menggunakan teknologi internet untuk perdagangan gelap narkotika. Dalam rangka menekan hal itu, pemerintah telah mengeluarkan instruksi presiden Nomor 6 Tahun 2018 tentang rencana aksi nasional pencegahan dan pemberantasan penyalahgunaan dan peredaran gelap narkotika. Berbagai upaya dalam penegakan hukum di bidang Narkotika telah banyak dilakukan oleh penegak hukum. Penegakan hukum digunakan sebagai solusi penyelesaian maraknya kasur Narkotika yang terjadi di Indonesia namun semakin gencarnya penegakan hukum, semakin banyak pula kasus peredaran dan penyalahgunaan narkotika (Kaligis \& Associates, 2002: 250).

Kabupaten Buleleng menduduki peringkat kedua tertinggi di Provinsi Bali. Hal ini menandakan bahwa pemberantasan narkotika di Kabupaten Buleleng belum berjalan secara maksimal. BNN Kabupaten Buleleng mengambil tindakan dengan melakuka sosialisasi mengenai peredaran, penyalahgunaan dan bahaya narkotika serta proses rehabilitasi. Berdasarkan wawancara dengan Kepala BNN Kabupaten Buleleng AKBP Made Astawa menyebutkan bahwa peredaran narkotika di Buleleng saat ini sangat memprihatinkan hingga menyasar masyarakat ke pelosok-pelosok desa sehingga dibutuhkan pengawasan mulai dari tingkat bawah hingga tingkat atas. Penuturan dari Kepala BNN Kabupaten Buleleng sejalan dengan kerjasama BNN dengan desa-desa untuk pemberantasan narkotika salah satunya Desa Pakraman Pancasari yang terletak di Kecamatan Sukasada, Kabupaten Buleleng.

Badan Narkotika Kabupaten Buleleng yang berkedudukan di Kabupaten Buleleng melakukan kerjasama dengan Desa Pancasari, Kecamatan Sukasada dalam hal pemberantasan penyalahgunaan dan peredaran gelap narkotika. Pencegahan, pemberantasan dan rehabilitasi narkoba tidak semerta-merta tugas dari BNN saja melainkan juga adalah tugas bersama seluruh lapisan masyarakat agar lebih berjalan maksimal. BNN juga pernah mengadakan sosialisasi tentang bahaya narkoba terhadap Perangkat Desa Pancasari pada tanggal 5 November 2019 di Desa Pancasari selain sosialisasi BNN juga mengadakan deteksi dini penyalahgunaan narkoba dengan cara tesr urine untuk mengetahui kepatutan perangkat desa yang sudah seharusnya menjadi contoh terhadap masyarakatnya. Kegiatan yang dilakukan BNN ini sejalah dengan instruksi presiden No. 6 Tahun 
2018 yang mewajibkan semua intansi kementrian maupun luar kementerian dari tingkat atas sampai bahwa termasuk perangkat desa agar bebas dari penyalahgunaan narkotika.

Dalam Pararem Desa Pakraman Pancasari mengatur mengenai larangan-larangan serta sanksisanksi yang akan diberikan kepada siapapun yang melakukan penyalahgunaan, peredaran gelap narkotika di kawasan Desa Pancasari termasuk aparat desa pakraman yang bahkan hukumannya akan dikenakan lebih berat karena aparat desa yang harusnya menjadi contoh bagi masyarakat desanya sehingga menurut penulis hasil kerjasama antara BNN dengan desa pakraman Pancasari yang mengasilkan sebuah pararem tentang narkotika untuk memberantas penyalahgunaan, peredaran gelap dan prekursor di Desa Pancasari akan berjalan maksimal apabila didukung oleh seluruh lapisan masyarakat di Desa Pancasari. Pembentukan pararem ini juga adalah sebuah terobosan pemberantasan narkotika dari lingkup terkecil masyarakat yang kadang tidak tersentuh dalam penanggulangannnya sehingga sangat diperlukan adanya bantuan pengawasan dari beberapa pihak yang dalam hal ini aparat desa dalam pencegahan terjadinya peredaran gelap narkotika.

Pengaturan sanksi yang diterapkan dalam pararem narkotika Desa Adat Pancasari berupa denda berupa barang dan juga melaksanakan upacara di desa tersebut. Upacara yang dilakukan akan diatur oleh pihak desa dengan tujuan untuk menyucikan kembali kondisi cemar yang telah dilakukan oleh pelaku pelanggaran pararem tersebut. Sanksi adat pada upacara pembersihan desa dari perasaan kotor (leteh) dalam prakteknya, berupa penyelenggaraan kegiatan yang bersifat niskala (alam gaib) yang penyebutannya ada bermacam-macam seperti uapakara pecaruan, pemarisuddan, pemrasyascita, malik sumpah dan lain sebagainya. Upacara dilaksanakan dengan menggunakan sarana dalam bentuk bebantenan (sesajen) yang disesuikan dengan sifat berat atau ringannya akibat yang ditimbulkan oleh pelanggaran adat (Suartha, 2015: 8).

\section{Efektivitas Pararem dalam Rangka Mencegah dan Memberantas Penyalahgunaan serta Peredaran Gelap Narkotika}

Pararem merupakan sebuah produk hukum adat yang bersifat dinamis. Pararem merupakan bukti hukum adat telah tumbuh mengikuti perubahan masyarakat melalui keputusan-keputusan dalam sebuah paruman (rapat adat). Hasil keputusan inilah kemudian yang dikenal dengan istilah pararem. Dalam beberapa buku dan literatur disebutkan mengenai pararem, namun tidak dijelaskan tentang pengertian secara jelas. Pararem timbul akibat dari sebuah fenomena atau gejala yang dianggap dapat mengganggu keseimbangan kehidupan masyarakat dimana dalam awig-awig hal tersebut tidak diatur atau sudah diatur dan isinya masih ambigu atau belum prinsip mengarah kepada gejala sosial yang dimaksud atau memerlukan peremajaan atau dari isi awig-awig tersebut sesuai dengan perkembangan kehidupan masyarakat untuk itu dibuatlah aturan tabahan awig-awig yang isinya adalah hasil musyarawah bersama di dalam rapat desa.

Dalam hal implementasi perarem narkotika di Desa Pakraman Pancasari melibatkan seluruh elemen masyarakat terutama pada pengawasan dan diharapkan apabila ada masyarakat yang mengetahui agar segera melaporkan ke pihak yang berwenang atau prajuru adat Desa Pakraman Pancasari. Penyalahgunaan dan peredaran gelap narkotika sudah menjadi masalah yang sangat kompleks bahkan sudah menjadi ancaman bagi suatu bangsa. Dalam Undang-Undang Nomor 35 Tahun 2009 Narkotika pada Pasal 112 Ayat (1) atas suatu perbuatan memiliki Narkotika golongan I dapat di penjara paling singkat 4 (empat) tahun dan paling lama 12 (dua belas) tahun dan pidana paling sedikit Rp.800.000.000,00 (Delapan ratus juta rupiah) dan paling banyak Rp.8.000.000.000,00 (Delapan miliyar rupiah).

Kemudian Pasal 112 ayat (2) UU Narkotika menyatakan bagi orang yang menyimpan, menguasai, atau menyediakan narkotika golongan I yang beratnya melebihi 5 (lima) gram diancam pidananya lebih berat, yaitu pidana penjara seumur hidup atau pidana penjara paling singkat 5 (lima) tahun dan paling lama 20 (dua puluh) tahun dan pidana denda maksimum sebagaimana disebutkan dalam Pasal 112 ayat (1) ditambah 1/3 (sepertiga). Selanjutnya orang yang menggunakan narkotika tanpa hak atau melawan hukum, orang tersebut dapat dipidana berdasarkan Undang- Undang Nomor 35 Tahun 2009 Narkotika Pasal 127 ayat (1) huruf a yang mengatakan bahwa setiap penyalahgunaan narkotika golongan I bagi diri sendiri dipidana dengan pidana penjara paling lama 4 (empat) tahun. Apabila penyalahgunaan tersebut dapat dibuktikan atau terbukti sebagai korban penyalahgunaan narkotika, penyalahguna tersebut wajib menjalani rehabilitasi medis dan rehabilitasi sosial. 
Dalam penegakan pararem tentang narkotika di Desa Pakraman Pancasari, BBN Kabupaten Buleleng mengambil peran besar dalam hal pembentukannya. Salah satunya adalah mengadakan sosialisasi terhadap masyarakat desa sebelum pembentukan pararem tersebut. Selain itu BNN Kabupaten Buleleng dan Pemerintah Desa Pakraman Pancasari membentuk kerjasama untuk pemberantasan peredaran dan penyalahgunaan narkotika dalam bentuk Pararem tentang narkotika di Desa Pakraman Pancasari. Dalam hal menanggulangi bahaya penyalahgunaan, peredaran gelap dan prekursor narkotika, pemerintah Desa Pancasari, Kecamatan Sukasada, Kabupaten Buleleng menerbitkan sebuah Pararem Desa Tentang Narkotika yaitu Pararem Desa Pancasari Kecamatan Sukasada Kabupaten Buleleng Sukerta Pawongan Ketertiban, Keamanan dan Bebas dari Penyalahgunaan dan Peredaran Narkotika/Sejenisnya Nomor 01/DPP-II/2019 tentang Narkotika/Sejenisnya yang merupakan hasil dari kerjasama dengan pihak Badan Narkotika Nasional Kabupaten Buleleng dalam rangka pemberantasan penyalahgunaan dan peredaran gelap narkotika.

Pada umumnya pararem bersisi ketentuan-ketentuan serta sanksi lanjutan dari awig-awig yang dirasa belum jelas namun tidak menutup kemungkinan pararem juga bisa dibuat untuk hal-hal tertentu yang belum dimuat dalam awig-awig (Artadi, 2012: 3). Di dalam beberapa kasus delik adat, sanksi adatnya dapat pula bersifat ganti rugi yang bersifat materiil maupun inmateriil. Pola pikir yang menghendaki upaya pemulihan adat dalam beberapa kasus delik pidana adat menunjukkan bahwa sifat masyarakat adat di Bali memiliki sistem budaya yang kuat dengan nilai-nilai yang bersifat religius. Hukum pidana adat yang masih hidup di dalam masyarakat adat Bali banyak dipengaruhi oleh unsur-unsur agama terutama agama Hindu (Widnyana, 1993: 19).

Sanksi adat ini dikenakan kepada siapapun yang telah melanggar pararem Desa Pakraman Pancasari tentang Narkotika baik itu pemerintah desa, masyarakat atau pendatang yang kedapatan melanggar ketentuan yang ada pada pararem tersebut dan untuk pemerintah desa apabila kedapatan melanggar ketentuan tersebut akan diberikan sanksi yang lebih berat daripada yang lainnya. Efektivitas sebuah pararem dalam penegakan pencegahan peredaran dan penyalahgunaan narkotika dikaitkan dengan teori M. Friendmen dalam Teori Sistem Hukum (Legal System Theory) mengenai efektif dan berhasil tidaknya penegakan hukum tergantung pada tiga unsur sistem yaitu struktur hukum, substansi hukum dan budaya hukum.

Apabila dikaji dari struktur hukum dalam penegakan pencegahan dan penyalahgunaan narkotika di Kabupaten Buleleng ini sudah berjalan dilihat dari dukungan BNN Kabupaten Buleleng dalam melakukan sosialisasi ke desa-desa mengenai dampak dari penyalahgunaan narkotika serta aktif menjalin kerjasama dengan desa dalam pencegahan peredaran dan penyalahgunaan narkotika. Kemudian dilihat dari substansi hukumnya dimana di Indonesia sendiri telah ada Undang-Undang No. 35 tahun 2009 tentang Narkotika yang dimana dalam aturan tersebut telah dimuat golongangolongan, kemudian sanksi-sanksi yang dapat dikenakan apabila sudah melanggar aturan tersebut.

Selanjutnya pembentukan pararem hasil kerjasama antara BNN Kabupaten Buleleng dengan Desa Pakraman yang memuat sanksi adat sehingga apabila ditemukan pelanggaran terhadap narkotika maka akan dikenai hukuman dari hukum nasional dan hukum adat di desa tersebut. Terakhir adalah budaya hukum yang disini adalah masyarakat. Apabila kita lihat dari masyarakat desa pakraman Pancasari baik yang menetap atau pendatang mulai dari pembentukan pararem hingga saat ini belum ada yang tersandung kasus narkotika karena mereka mengetahui dan paham pembentukan pararem tersebut memiliki tujuan positif. Hal itu juga didapatkan dari sosialisasi setelah pararem terbentuk mengenai bahaya penggunaan narkotika serta sanksi adat yang akan dikenakan kepada mereka yang melanggar sehingga berdasarkan teori ini pararem tentang Narkotika Desa Pakraman Pancasari sudah efektif.

\section{SIMPULAN DAN SARAN}

1. Simpulan

Adapun kesimpulan dari pembahasan tersebut diatas:

a. kerja sama yang dilakukan BNN dan desa adat dalam mencegah dan memberantas penyalahgunaan serta peredaran gelap narkotika dan prekursor narkotika adalah dengan mengadakan sosialisasi mengenai bahaya narkotika salah satu contohnya adalah BNN Kabupaten Buleleng yang bekerjasama dengan Desa Adat Pancasari dalam memerangi narkotika, selain melaksanakan sosialisasi dan tes urine, BNN kabupaten Buleleng dan juga Desa Adat Pancasari menerbitkan sebuah pararem Desa Adat Pancasari Nomor 01/DPP- 
II/2019 tentang narkotika yang akan digunakan sebagai acuan penyelenggaraan pemberantasan penyalahgunaan serta peredaran gelap narkotika dan prekursor narkotika di Desa Adat Pancasari yang merupakan salah satu desa wisata yang banyak dikunjungi wisatawan asing dan domestik.

b. Efektivitas Pararem Desa Pancasari Tentang Narkotika dalam rangka mencegah dan memberantas penyalahgunaan serta peredaran gelap narkotika dan prekursor narkotika di Desa Pancasari, Kecamatan Sukasada,Kabupaten Buleleng sudah berjalan efektif dengan dukungan penuh pemerintah desa dan masyarakat adat serta didukung penuh oleh BNN Kabupaten Buleleng sehingga sampai saat ini belum ada pelanggaran terkait penyalahgunaan serta peredaran gelap dan prekursor narkotika di Desa Adat Pancasari karena semua bersinergi dengan keyakinan penuh untuk pemberantasan narkotika mulai dari ruang lingkup masyarakat terkecil yaitu desa guna mencegah atau meminimalisir tempat-tempat kecil yang dimanfaatkan oleh pengedar narkotika.

2. Saran

a. Narkotika merupakan ancaman bagi keutuhan bangsa sehingga pemerintah khususnya pemerintah daerah yang belum menyelenggarakan kerjasama dengan desa adat dalam hal pemberantasan narkotika terutama kawasan wisata karena sangat penting untuk membatasi ruang gerak pelaku tindak pidana narkotika dari lingkup masyarakat terkecil.

b. Peredaran gelap dan penyalahgunaan narkotika merupakan ancaman besar bagi kehidupan masyarakat terutama generasi muda sehingga sudah seharusnya bagi masyarakat untuk menghindari tersangkut paut dengan narkotika serta mendukung program pemerintah agar berjalan efektif dalam pencegahan peredaran gelap dan penyalahgunaan narkotika untuk membentuk karakter bangsa yang baik.

\section{DAFTAR PUSTAKA}

Artadi, I. K. (2012). Hukum Adat Bali dengan Aneka Masalahnya. Pustaka Bali Post.

Hariyono, B. (2009). Kebijakan Formulasi Sanksi Pidana terhadap Pelaku Tindak Pidana Narkoba di Indonesia [Universitas Diponegoro].

Kaligis, O., \& Associates. (2002). Narkoba dan Peradilannya di Indonesia: Reformasi Hukum Pidana Melalui Perundangan dan Peradilan. Alumni.

Makaro, M. T., \& Dkk. (2005). Tindak Pidana Narkotika. Ghalia Indonesia.

Sanger, E. C. (2013). Penegakan Hukum terhadap Peredaran Narkoba di Kalangan Generasi Muda. Lex Crimen, 2(4), 5-13.

Soerjono, S. (1986). Pengantar Penelitian Hukum. Universitas Indonesia Press.

Suartha, I. D. M. (2015). Hukum dan Sanksi Adat (Persfektif Pembaharuan Hukum Pidana). Setara Press.

Widnyana, I. M. (1993). Kapita Selekta Hukum Pidana Adat. PT Eresco.

Undang-Undang Nomor 39 Tahun 1999 Tentang Hak Asasi Manusia (Lembaran Negara Republik Indonesia Tahun 1999 Nomor 165, Tambahan Lembaran Negara Republik Indonesia Nomor 3886).

Undang-Undang Nomor 35 Tahun 2009 Tentang Narkotika (Lembaran Negara Republik Indonesia Tahun 2009 Nomor 143, Tambahan Lembaran Negara Republik Indonesia Nomor 5062).

Peraturan Presiden Republik Indonesia Nomor 40 Tahun 2013 Tentang Pelaksanaan UndangUndang No. 35 Tahun 2009 tentang Narkotika (Lembaran Negara Republik Indonesia Tahun 2013 Nomor 96, Tambahan Lembaran Negara Republik Indonesia Nomor 5419).

Peraturan Presiden Republik Indonesia Nomor 23 Tahun 2010 Tentang Badan Narkotika Nasional.

Peraturan Daerah Provinsi Bali Nomor 4 Tahun 2019 tentang Desa Adat.

Pararem Desa Adat Pancasari Nomor: 01/DPP-II/2019 Tentang Narkotika/Sejenisnya. 